\title{
ANALISIS STRUKTUR MODAL TERHADAP PERTUMBUHAN LABA PERUSAHAAN PADA PT PLN (PERSERO) DAN ANAK PERUSAHAAN
}

\author{
Patar Simamora \\ Dosen Tetap Fakultas Ekonomi \\ Universitas Pakuan \\ Rahmat Yusuf \\ Mahasiswa Fakultas Ekonomi \\ Universitas Pakuan
}

\begin{abstract}
ABSTRAK
Struktur modal adalah komposisi dan proporsi utang jangka panjang dan ekuitas yang ditetapkan oleh perusahaan untuk mendanai operasinya. Perusahaan yang mampu mengelola modal modal dan utang mereka sendiri baik itu akan menghasilkan struktur modal yang optimal, sehingga meningkatkan pertumbuhan laba perusahaan.

Metode yang digunakan adalah penulis metode studi kasus, sedangkan jenis penelitian adalah deskriptif eksploratif. Metode analisis yang digunakan adalah dengan menggunakan metode analisis kuantitatif, alat analisis yang digunakan dalam penelitian ini adalah dengan menggunakan rumus yang berkaitan dengan struktur modal dan pertumbuhan laba perusahaan.

Berdasarkan analisis struktur modal terhadap pertumbuhan laba perusahaan dapat disimpulkan tidak baik, hal ini disebabkan struktur modal secara keseluruhan tidak mempengaruhi pertumbuhan laba perusahaan. Faktor-faktor yang mempengaruhi pertumbuhan laba perusahaan dalam analisis ini tidak hanya rasio utang pada rasio lancar, modal dan pertumbuhan penjualan.
\end{abstract}

Kata kunci: Current Ratio, ekuitas, utang dan pertumbuhan penjualan

\section{Pendahuluan}

Dalam kegiatan usaha yang dijalankan suatu perusahaan tentu memiliki beberapa tujuan yang ingin dicapai oleh pemilik dan manajemen yang diantaranya pemilik perusahaan menginginkan keuntungan (Laba) atas usaha yang dijalankannya.

Struktur modal merupakan masalah yang penting bagi perusahaan karena baik buruknya struktur modal akan mempunyai efek langsung terhadap posisi finansial perusahaan sehingga dapat diketahui nilai keuntungan suatu perusahaan pada suatu saat tertentu karena rentabilitas merupakan kemampuan perusahaan dalam menghasilkan keuntungan dengan semua modal yang berada di dalamnya. 
Sumber pembiayaan dapat diperoleh dari modal sendiri dan modal pinjaman (Hutang), Oleh karena itu struktur modal adalah salah satu keputusan keuangan yang berhubungan dengan pencapaian tujuan perusahaan. Tujuan penelitian ini antara lain: 1. Untuk mengetahui analisis struktur modal pada PT. PLN (persero) dan anak perusahaan, 2. Untuk mengetahui pertumbuhan laba perusahaan pada PT. PLN (persero) dan anak perusahaan, dan 3. Untuk menganalisis struktur modal terhadap pertumbuhan laba perusahaan pada PT. PLN (persero) dan anak perusahaan.

\section{Metode Penelitian}

Jenis penelitian ini menggunakan metode deskriptif analisis, metode penelitian yang penulis gunakan adalah studi kasus dan studi kepustakaan, teknik yang digunakan adalah statistik kuantitatif, dan metode analisis yang digunakan dalam penelitian ini adalah metode analisis kuantitatif.

\section{Hasil Penelitian}

Hasil analisis struktur modal dengan menggunakan indikator current ratio, modal sendiri, debt ratio dan growth of sales terhadap pertumbuhan laba perusahaan dengan menggunakan net profit margin, contribution margin, return on asset dan return on equity sebagai indikator.

Dari tahun 2007-2008 pertumbuhan cukup baik ditunjukan growth of sales tetapi tidak pada current ratio, modal sendiri dan debt ratio. Penurunan current ratio disebabkan dari tahun 2007-2008 current ratio perusahaan mengalami penurunan dari 107,29\% pada tahun 2007 menjadi 76,43\% pada tahun 2008, hal tersebut disebabkan pertumbuhan current liabilities dari tahun 2007-2008 sebesar 0,93\% lebih tinggi dari pada pertumbuhan current asset yang dimiliki perusahaan sebesar $-28,08 \%$. Kemudian penurunan modal sendiri dari 136.412.740 pada tahun 2007 menjadi 126.986 .567 pada tahun 2008, hal tersebut disebabkan pertumbuhan total liabilities sebesar 26.665.181 lebih tinggi dari pada pertumbuhan total asset sebesar 17.239.008. Dan pertumbuhan debt ratio dari 50,11\% pada tahun 2007 menjadi $56,31 \%$ pada tahun 2008, hal tersebut disebabkan pertumbuhan liabilities dari tahun 20072008 sebesar 19,45\% lebih tinggi dari pada pertumbuhan total asset sebesar 6,30\%. Diikuti dengan penurunan net profit margin, peningkatan contribution margin, penurunan return on asset dan penurunan return on equity. Penurunan net profit dari -7,39\% pada tahun 2007 menjadi $-14,60 \%$ pada tahun 2008 , hal tersebut disebabkan pertumbuhan sales $10,43 \%$ lebih 
tinggi dari pada pertumbuhan EAT sebesar $-117,95 \%$. Kemudian peningkatan contribution margin dari 3,32\% pada tahun 2007 menjadi 4,28\% padda tahun 2008, hal tersebut disebabkan pertumbuhan GPM 42,33\% lebih tinggi dari pada pertumbuhan sales sebesar 10,43\%. Kemudian penurunan return on asset dari -2,06\% pada tahun 2007 menjadi -4,23\% pada tahun 2008, hal tersebut disebabkan pertumbuhan total asset sebesar 6,30\% lebih tinggi dari pada pertumbuhan EAT sebesar -117,95\%. Dan penurunan return on equity dari $-413 \%$ pada tahun 2007 menjadi $-9,68 \%$ pada tahun 2008, hal ini disebabkan pertumbuhan modal sendiri turun sebesar -6,91\% lebih tinggi dari pada pertumbuhan EAT sebesar -117,95\%.

Kemudian dari tahun 2008-2009 pertumbuhan cukup baik ditunjukan current ratio, modal sendiri dan growth of sales tetapi tidak dengan debt ratio. Debt ratio perusahaan mengalami peningkatan dari 56,31\% pada tahun 2007 menjadi 57,68\% pada tahun 2008, hal tersebut disebabkan pertumbuhan liabilities perusahaan sebesar 17,58\% lebih tinggi dari pada pertumbuhan total asset sebesar 14,78\%. Diikuti dengan peningkatan net profit margin, contribution margin, return on asset dan return on equity. Peningkatan net profit margin sebesar 26,48\% dari $-14,60 \%$ pada tahun 2008 menjadi 11,48\% pada tahun 2009. Kemudian peningkatan contribution margin sebesar 6,57\% dari 4,28\% pada tahun 2008 menjadi $11,03 \%$ pada tahun 2009 . Kemudian peningkatan return on asset sebesar 7,33\% dari $-4,23 \%$ pada tahun 2008 menjadi 3,10\% pada tahun 2009. Dan peningkatan return on equity sebesar $17,01 \%$ dari $-9,68 \%$ pada tahun 2008 menjadi 7,33\% pada tahun 2009.

Kemudian dari tahun 2009-2010 pertumbuhan cukup baik ditunjukan modal sendiri dan growth of sales tetapi tidak dengan current ratio dan debt ratio. Current ratio perusahaan mengalami penurunan sebesar $16,64 \%$ dari $98,12 \%$ pada tahun 2009 menjadi $81,48 \%$ pada tahun 2010, hal tersebut disebabkan pertumbuhan current liabilities sebesar 45,72\% lebih tinggi dari pada pertumbuhan current asset sebesar 21,01\%. Dan pertumbuhan debt ratio mengalami peningkatan sebesar $1,77 \%$ dari $57,68 \%$ pada tahun 2009 menjadi $59,45 \%$ pada tahun 2010, hal ini disebabkan pertumbuhan hutang sebesar 14,78\% lebih tinggi dari pada pertumbuhan total asset sebesar 10,63\%. Diikuti dengan peningkatan contribution margin sebesar 1,85\% dari 11,03\% pada tahun 2009 menjadi 12,88\% pada tahun 2010. Tetapi tidak diikuti dengan net profit margin, return on asset dan return on equity. Pertumbuhan net profit margin mengalami penurunan sebesar $1,68 \%$ dari $11,48 \%$ pada tahun 2009 menjadi 9,80\% pada tahun 2010, hal ini disebabkan pertumbuhan sales sebesar 14,19\% lebih tinggi dari pada pertumbuhan EAT sebesar -2,53\%. Penurunan return on asset sebesar $0,37 \%$ dari $3,10 \%$ pada tahun 2009 menjadi 2,73\% pada tahun 2010, hal ini disebabkan pertumbuhan total asset 
sebesar 10,63\% lebih tinggi dari pada pertumbuhan earning after tax sebesar -2,53\%. Dan penurunan return on equity sebesar $0,59 \%$ dari 7,33\% pada tahun 2009 menjadi $6,74 \%$ pada tahun 2010, hal ini disebabkan pertumbuhan modal sendiri sebesar 6,01\% lebih tinggi dari pada pertumbuhan EAT sebesar $-2,53 \%$.

Kemudian dari tahun 2010-2011 pertumbuhan cukup baik ditunjukan current asset, modal sendiri dan growth of sales tetapi tidak dengan debt ratio. Debt ratio mengalami peningkatan sebesar 4,12\% dari 59,45\% pada tahun 2010 menjadi 63,57\% pada tahun 2011, hal ini disebabkan pertumbuhan hutang sebesar 23,53\% lebih tinggi dari pada pertumbuhan total asset sebesar 15,52\%. Diikuti dengan peningkatan contribution margin sebesar 0,07\% dari $12,88 \%$ pada tahun 2010 menjadi 12,95\% pada tahun 2011. Akan tetapi tidak diikuti dengan net profit margin, return on asset dan return on equity. Penurunan net profit margin sebesar 3,43\% dari 9,80\% pada tahun 2010 menjadi 6,37\% pada tahun 2011, hal ini disebabkan pertumbuhan sales sebesar 9,58\% lebih tinggi dari pada pertumbuhan EAT sebesar $-28,72 \%$. Penurunan return on asset sebesar 1,05\% dari 2,73\% pada tahun 2010 menjadi $1,68 \%$ pada tahun 2011, hal ini disebabkan pertumbuhan total asset sebesar $15,52 \%$ lebih tinggi dari pada pertumbuhan EAT sebesar -28,72\%. Dan penurunan return on equity sebesar 2,11\% dari 6,74\% pada tahun 2010 menjadi 4,63\% pada tahun 2011, hal ini disebabkan pertumbuhan modal sendiri sebesar 3,78\% lebih tinggi dari pada pertumbuhan EAT sebesar $-28,72$.

\section{Kesimpulan}

Berdasarkan hasil perhitungan dengan menggunakan indikator current ratio, modal sendiri, debt ratio dan growth of sales bahwa struktur modal pada PT. PLN (persero) dan Anak Perusahaan kurang baik.

Berdasarkan perhitungan dengan menggunakan indikator net profit margin, contribution margin, return on asset dan return on equity bahwa pertumbuhan laba perusahaan pada PT. PLN (persero) dan Anak Perusahaan kurang baik.

Berdasarkan hasil analisis struktur modal terhadap pertumbuhan laba perusahaan, secara keseluruhan struktur modal tidak mempengaruhi pertumbuhan laba perusahaan dan hanya debt ratio yang mempengaruhi net profit margin, return on asset dan return on equity yang mempengeruhi pertumbuhan laba perusahaan. Berdasarkan hal tersebut dapat diambil 
kesimpulan bahwa analisis struktur modal tidak berpengaruh terhadap pertumbuhan laba perusahaan.

\section{Daftar Pustaka}

Ahmad Rodoni. 2010. Manajemen Keuangan, edisi pertama, penerbit : Mitra Wacana Media, Jakarta.

Agus Harjito, dan Martono. 2012. Manajemen Keuanagan, edisi kedua, penerbit : Ekonesia, Yogyakarta.

Ali Kesuma. 2009. Analisis Faktor yang Mempengaruhi Struktur Modal serta Pengaruhnya terhadap Harga Saham Perusahaan Real Estate yag Go Publik di BEI, Jurnal Manajemen dan Kewirausahaan, Vol. 11. No. 1 hal : 38-45.

Alfredson, Keith, Ken Leo and Janice Loftus, 2009, Applying International Financial Reporting Standard, 2 nd Edition, National Library of Australia

Beasley, Scott, Eugene F Bringham, 2008, Essential of Managerial Finance, Fourteenth Edition, Thomson High Education 519 Notorp Boulevered Mason, OH 45040 USA.

Bringham, Eugene F, Joel F Houston, 2009, Fundamental of Financial Management, Twelfth Edition, Frentice Hall, New York.

Darsono Prawironegoro, dan Ari Purwanti. 2008. Penganggaran Perusahaan, penerbit : Mitra Wacana Media, Jakarta.

Darson Prawironegoro. 2010. Manajemen Keuangan, Penerbit : Nusantara Consulting, Jakarta.

Deramawan Sjahrial. 2012. Pengantar Manajemen Keuangan, Edisi Keempat, Mitra Wacana Media, Jakarta

Farah Margaretha. 2012. Menejemen Keuangan untuk Manajer non Keuangan, Penerbit : Erlangga.

Fraser, Lyn M, dan Ailen Orniston. 2008. Memahami Laporan Keuangan, edisi ketujuh, (terjemahan) penerbit : PT. Indeks, Jakarta.

Harmono. 2009. Manajemen Keuangan, edisi pertama, cetakan pertama, Penerbit : Bumi Aksara, Jakarta.

Handono Mardiyanto. 2009. Inti Sari Manajemen Keuangan Teori, Soal,dan Jawaban. Grasindo. Jakarta.

Husen Umar. 2011. Metode Penelitian untuk Skripsi dan Tesis Bisnis, penerbit : Rajawali Pers, Jakarta. 
Analisis Struktur Modal terhadap Pertumbuhan Laba Perusahaan pada PT PLN (Persero) dan Anak Perusahaan

Hery. 2011. Akuntansi Keuangan Menengah 2, cetakan pertama, penerbit : PT. Bumi Aksara, Jakarta.

Irham Fahmi. 2012. Analisis Laporan Keuangan, cetakan kedua penerbit Alfabeta, Bandung 